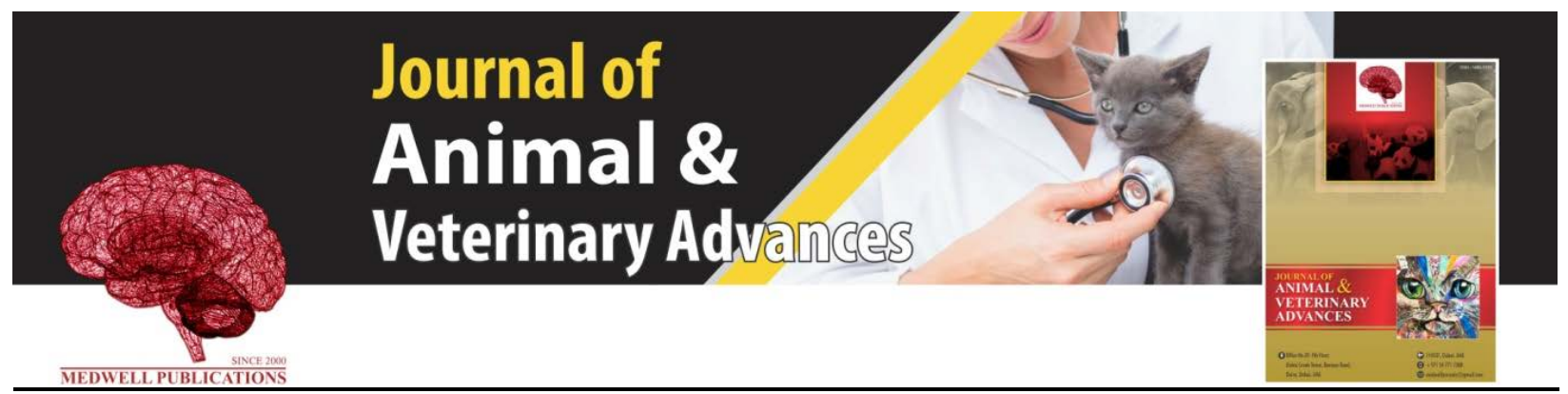

\title{
Importance-Performance Analysis toward Productivity of Bali Cattle Based on Agroecosystem in Timor Island
}

Fellyanus Habaora, Asnath Maria Fuah, Luki Abdullah, Rudy Priyanto, Ahmad Yani and Bagus Priyo Purwanto

Department of Post Graduate Programme Animal Production and Technology, Faculty of Animal Husbandry 16680, Bogor Agricultural University, Jl. Agatis, Babakan-Dramaga, Bogor, West Java, Indonesia

Key words: Importance-performance analysis, productivity, agroecosystems, cattle, pasture

Corresponding Author:

Fellyanus Habaora

Department of Post Graduate Programme Animal Production and Technology, Faculty of Animal Husbandry 16680, Bogor Agricultural University, Jl. Agatis, Babakan-Dramaga, Bogor, West Java, Indonesia

Page No.: 57-66

Volume: 19, Issue 5, 2020

ISSN: 1680-5593

Journal of Animal and Veterinary Advances Copy Right: Medwell Publications
Abstract: The aim of this study was to determine the productivity aspects (production and reproduction) of Bali cattle based on agroecosystems that include pasture, agriculture, plantation and forest on Timor Island. Therefore, from January-December 2018, research on the performance of Bali cattle production-based agroecosystem was conducted. The research location was chosen purposively representing agroecosystems of pasture, agriculture, plantation and forest. The number of respondents was $5-10 \%$ of the number of cattle farmers in each agroecosystem that had $>10$ Bali cattle. The respondents were interviewed using a questionnaire prepared. Field observations were also conducted to measure the performance of Bali cattle production. The data analysis used the Importance-Performance Analysis method which was processed through a computerized SPSS program and the results were explained descriptively. The results of this study indicated that the level of importance and performance of Bali cattle in the pasture, agriculture, plantation and forest agroecosystems showed the same conditions where the performance (productivity) of Bali cattle in each agroecosystem was good for such attributes as body weight, calf crop, and conception rate. Meanwhile, the attributes that need to be considered and improved are the quality and quantity of SKT, oestrus age, first coitus age, oestrus cycle, oestrus duration, service per conception, length of calf pregnancy, age of first calving, days open, calving interval and rate of increase population. Thus the productivity of Bali cattle scattered in pasture, agriculture, plantation and forest agro-ecosystems in general is still low. 


\section{INTRODUCTION}

Bali cattle productivity is influenced by genetic, environmental and production and reproduction management based on age. While genes affect performance, the environment is a cumulative factor that affects the growth and development of cattle from the moment of conception to adulthood and age indicates the ability of bodily functions to produce and reproduce ${ }^{[1,2,3]}$.

Livestock production can be described by measuring the physical characteristics of livestock such as livestock body weight measurement and body scoring. Weight gain has a correlation with body scoring. When bone growth occurs rapidly, the muscle growth decreases and fat deposition increases after puberty. Body scoring is used to assess the appearance of an animal from bodily conditions such as fat, thin or visually ideal or palpable on a pile of body fat under the skin around the base of the tail, backbone and hips expressed by scoring. Body condition scores are useful in evaluating feeding, assessing the health status of individual animals and important indicators in assessing animal reproductive potential $^{[3]}$.

Assessment of Bali cattle reproduction can be done through measurement assessments of calf crop, natural increase, mortality, natality, conception rate, service period, service per conception, calving interval and calving rate. The results of the assessment of livestock reproduction measurements are strongly influenced by oestrus age, first coitus age, oestrus cycle, oestrus duration The success of livestock reproduction status is the increased rate of livestock population $^{[3,4]}$.

The productivity of Bali cattle from genetic and environmental influences tend to differ from one agroecosystem to another. An agroecosystem is a causal loop relationship between components and factors forming ecosystems (abiotic and biotic) to productivity, stability, sustainability and equity. So, far there has been no information and data that can provide a clear picture of the level of productivity of Bali cattle in different agroecosystems. One area that has the potential to develop agroecosystem-based livestock business is Timor Island $^{[3,4] \text {. }}$

Timor Island in East Nusa Tenggara province is one of the highest Bali cattle supply areas to be slaughtered as a source of meeting the needs of national meat which is $60 \%$ concentrated in DKI Jakarta, West Java and Banten Provinces. However, the aspect of production and reproduction of Bali cattle on the Timor Island continues to experience degradation as indicated by several research results that report that: the death of Bali calves is very high (35-40\% per year), the death of Bali cows is high (> $20 \%$ per year), slaughter of productive females in RPH reaches $>60 \%$ of total slaughter of cows, input of Bali cattle production is still low due to traditional raising management and a decrease in body weight of Bali cattle from $450 \mathrm{~kg} /$ head in the $1970-1980$ s to $275 \mathrm{~kg} \mathrm{head}^{-1}$ in $2015^{[2-5,9,10,12]}$.

One of the factors influencing the productivity decline of Bali cattle on Timor Island is the policy and management of animal husbandry, both those carried out by the breeder community and the government, not paying enough attention to the potential of agroecosystems in supporting the success of the productivity of Bali cattle. Therefore, we need an in-depth study using a varied agroecosystem approach to the conditions of livestock farming on Timor Island. The agroecosystem based on land use type consists of pasture, agriculture, plantation and forest agroecosystems. Thus the purpose of this research was to find out the aspects of productivity (production and reproduction) of Bali cattle based on agroecosystems which include pasture, agriculture, plantation and forest agroecosystems on Timor Island.

\section{MATERIALS AND METHODS}

Experimental Site. This research was conducted in from: January-December, 2018 on the island of Timor. Agroecosystem locations were determined purposively based on physical (land area), biological (agroecosystem), and social criteria so that the sampling locations representing pasture agroecosystems are the Regencies of Belu, Malaka, Timor Tengan Utara (TTU). The agricultural agroecosystems are represented by Kupang Regency and Kupang city, the plantation agroecosystems by Kupang regency and the forest agroecosystems by the regency of Timor Tengan Selatan (TTS).

Materials and research tools: The material used is Balinese cattle which are in four agroecosystem locations. The respondents are $5-10 \%$ of the number of the farmers in each agroecosystem that has $>10$ Bali cattle.

Data collection and parameters measured: The respondents were interviewed for data collection on reproductive responses using questionnaires covering the reproductive status of livestock, namely oestrus age, first coitus age, oestrus cycle, oestrus duration, service per conception, length of calf pregnancy, age of first calving, days open, calving interval and rate of increase population. Production data obtained by direct observation to the field to measure linear body, so that, the body weight of cattle and body scoring of Bali cattle can be estimated based on agroecosystems on the island of Timor. Estimation of body weight is based on the instructions by Surahmah and The ${ }^{[13]}$ that is $\mathrm{BB}=$ 


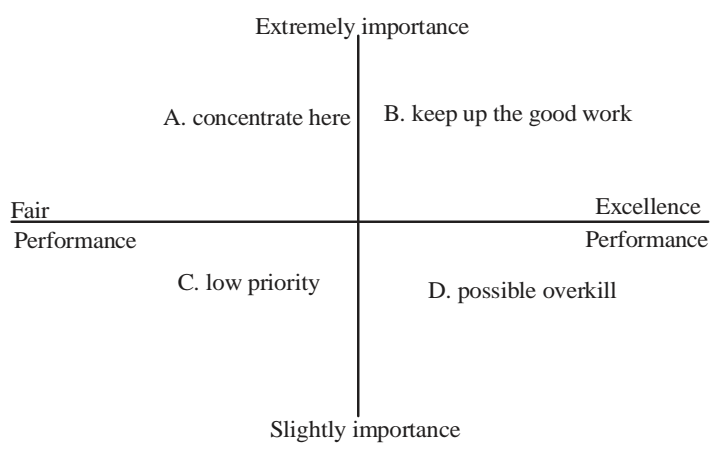

Fig. 1: Cartesian diagram

2.36LD+0.78PB-236. Meanwhile, the bo dy condition Score (SKT) of Bali cattle was measured based on the Rutter etc., namely SKT 1 (very thin), SKT 2 (thin), SKT 3 (moderate), SKT 4 (fat) and SKT 5 (very fat).

Statistical analysis: Data analysis uses ImportancePerformance Analysis (IPA) according to the instructions by Algifari ${ }^{[14]}$ which is one methodology tool introduced by Martilla and James to facilitate the identification of attributes based on their respective interests such as good-bad, important-not important, etc. using the SPSS program which is carried out in the following stages. Determining the comparative elevel of the compatibility between the existing condition and expectation. The suitability (Eq. 1) used is:

$$
\mathrm{Tki}=\frac{\mathrm{X}_{\mathrm{i}}}{\mathrm{Y}_{\mathrm{i}}} \times 100 \%
$$

Where:

Tki $=$ Suitability level

$\mathrm{X}_{\mathrm{i}}=$ Attribute of existing condition

$\mathrm{Y}_{\mathrm{i}}=$ Attribute of conditions of sustainability expectation

Calculating the average for each production system attribute of Bali cattle using the equation:

$$
\overline{X_{i}}=\frac{\sum X i}{n} \bar{Y}_{i}=\frac{\sum Y i}{n}
$$

Where:

$\overline{\mathrm{X}_{\mathrm{i}}}=$ Average score of existing condition attributes

$\bar{Y}_{\mathrm{i}}=$ Average score of expectation

$\mathrm{n}=$ Number of samples

Calculating the average of all the existing condition Attributes (X) and Expectations (Y) which are the boundaries in the Cartesian diagram using the equation:

$$
\overline{\overline{\mathrm{X}}}=\frac{\overline{\sum \mathrm{X}_{\mathrm{i}}}}{\overline{\mathrm{Y}}}=\frac{\overline{\sum \mathrm{Y}_{\mathrm{i}}}}{\mathrm{k}}
$$

Where:

$\overline{\overline{\mathrm{X}}}=$ Average of the average score of existing condition attributes

$\overline{\bar{Y}}=$ Average of the average score of expectations

$\mathrm{k}=$ The number of attributes that affect the production system

The description of each attribute in the Cartesian diagram (Fig. 1).

\section{Information:}

- Quadrant A is a top priority where the level of importance is high but the level of performance is low

- Quadrant B is an achievement where the level of importance and the level of performance are both high or already good

- Quadrant C is a low priority which indicates that the attributes that are considered less important

- Quadrant D is excessiveness which shows that the attributes that are considered less important but the performance shows very good or satisfying so this is considered to be very excessive

The attributes used in livestock production systems are the ability of livestock production and livestock reproduction performance.

\section{RESULTS AND DISCUSSION}

Bali cattle productivity based on agroecosystems on Timor island: The description of Bali cattle productivity can be learned and measured from the production and reproduction performance of the cattle. Bali cattle production is a display of cattle body weight and the scoring of cattle body to age. Meanwhile, the reproductive status is known from the physiological state of the body which describes the states of oestrus age, first coitus age, oestrus cycle, oestrus duration which affect the state of calf crop, service per conception, length of calf pregnancy, age of first calving, days open, calving interval, conception rate and have an impact on the rate of livestock population increase. Information and data on the display of Bali cattle productivity based on the agroecosystems of Timor Island are presented in Table 1. Information and data in Table 1 shows that the average body weight of Bali cattle in the pasture agroecosystem at 3.9 years of age is $229.3 \mathrm{~kg}$, in the agriculture agroecosystem at 3.6 years of age $188 \mathrm{~kg}$ in the plantation agroecosystem at 3.5 years of age $227.5 \mathrm{~kg}$ and in the forest agroecosystem at 3.7 years of age $194.9 \mathrm{~kg}$. This study shows that the weight of Bali cattle in the pasture and plantation agroecosystems is higher than in the forest 
J. Anim. Vet. Adv., 19 (5): 57-66, 2020

Table 1: Display of Bali cattle productivity based on agroecosystems in timor Island

\begin{tabular}{|c|c|c|c|c|c|c|}
\hline \multirow[b]{2}{*}{ Variables } & \multirow[b]{2}{*}{ Units } & \multicolumn{5}{|c|}{ Performance } \\
\hline & & Pasture & Agriculture & Plantation & Forest & Importance \\
\hline Body weight & (kg) & 229.3 & 188.0 & 227.5 & 194.9 & 275.0 \\
\hline Body condition score & - & 3.1 & 3.6 & 3.2 & 3.5 & 3.0 \\
\hline Age of puberty & (Year & 1.3 & 1.4 & 1.3 & 1.4 & 1.1 \\
\hline Female age of first mate & (Year) & 1.9 & 1.7 & 2.0 & 1.8 & 1.5 \\
\hline Oestrus cycle & (Day) & 26.7 & 24.0 & 23.8 & 24.8 & 21.0 \\
\hline Calf crop & (\%) & 62.8 & 51.4 & 32.7 & 54.7 & 70.0 \\
\hline Oestrus length & (Hours) & 21.5 & 28.0 & 25.8 & 26.8 & 18.5 \\
\hline Service per conception & (Unit) & 2.4 & 2.6 & 2.2 & 2.3 & 1.8 \\
\hline Length of pregnancy & (Month) & 9.3 & 9.4 & 9.5 & 9.2 & 9.6 \\
\hline Age of first partus & (Year) & 2.9 & 2.8 & 3.0 & 2.9 & 2.1 \\
\hline Days open & (Month) & 8.0 & 9.0 & 1.1 & 1.0 & 3.5 \\
\hline Calving interval & (Year) & 2.3 & 2.7 & 2.8 & 2.4 & 1.0 \\
\hline Conception rate & $(\%)$ & 50.3 & 53.4 & 33.7 & 56.0 & 65.0 \\
\hline Natural increase & (\%) & 11.1 & 8.6 & 7.4 & 11.2 & 35.0 \\
\hline
\end{tabular}

and agriculture agroecosystems at ages 3.5-3.9 years. However, this study shows the low state of productivity of Bali cattle when compared to the results of the study of Baharun et al. ${ }^{[15]}$ who reported the weight of Bali cattle at age 2.1 years reaching $207.4 \mathrm{~kg}$. The difference in Bali cattle weight in the results of this study is probably due to the negative selection related to the long-term crossbreeding (inbreeding) that has lasted for a long time in the traditional cattle breeding system. Warwick et al. ${ }^{[16]}$ stated that inbreeding in cattle resulted in a decrease in body weight of $2.5-5.0 \mathrm{~kg}$ per $10 \%$ increase in crosssection. Thus the results of this study indicate that cattle body weight has a correlation to the environmental conditions, genetic makeup and age. Some research results report that the performance of Bali cattle weight is the result of genetic and cumulative environmental effects experienced by the cattle. The environmental conditions cause phenotypic responses that are less compatible with the genetic potential of the cattle. In the meantime, age shows the ability of bodily functions to produce and reproduce. The accumulation of genetic, environmental and age influences also has a positive correlation to the body condition score of Bali cattle ${ }^{[17,18]}$.

Body condition scoring (SKT) of Bali cattle is a parameter that can be used to evaluate the nutritional status of Bali cattle. Body condition is an indication of the energy storage reserves of cattle which is an important factor in influencing livestock production and reproduction. The HCS information and data in Table 2 shows that the average HCS in Bali cattle in the agroecosystems of pasture, agriculture, plantation and forest is quite fat (SKT 3) with the highest SKT value being in the agroecosystem of agriculture--SKT 3.6, forests SKT 3.5, plantations SKT 3.2 and pastures SKT 3.1. However, the SKT value of Bali cattle from this study is still low compared to the results of the research by Baharun et al. ${ }^{[19]}$ who reported the SKT value of Bali cattle on Timor Island averaged 3.97. The difference in
SKT value from the results of this study is very likely to be influenced by the condition of feed availability in each agroecosystem on the island of Timor at the time of the study. The SKT value of cattle in addition to being influenced by the cattle breed, it is also strongly influenced by the feeding management in terms of quantity and quality for example, good quality feed which is given in sufficient quantities will increase livestock productivity ${ }^{[20,21]}$. Suretno et al..$^{[22]}$ states that Bali SKT is strongly influenced by altitude and climate. Thus the performance of Bali cattle production is strongly influenced by differences in agroecosystems.

Data and information on oestrus age and first coitus age for female Bali cattle in Table 1 shows that the average age of Bali cattle for experiencing heat time in the agroecosystems of pasture, agriculture, plantation and forest is $>1.1$ years, making it a long time for female Bali cattle ready to mate, $>1.7$ years. Normally, the first oestrus of Bali cattle is at age 1.1 years and the first coitus is at age 1.5 years $^{[23]}$. The different ages in the first oestrus and coitus were strongly influenced by feed management factors, so that, it is necessary to improve the aspect of feed for female cattle in the agroecosystems on the island of Timor. The earlier age of female oestrus (puberty) benefits breeders because it can reduce the unproductive period of female cattle and prolong the productive life cycle of livestock. Meanwhile, young female cattle should not be mated until their body growth allows for pregnancy and normal birth because adult sex occurs before the adult body is reached. Habaora et al. ${ }^{[23]}$ states that puberty is influenced by animal conditions (age, body weight, race and genetics) and environment (temperature, season and climate) as well as the availability of feed in terms of quantity and quality.

The cattle age to have a baby for the first time in the agricultural agroecosystem is younger that is 2.8 years, compared to in the pasture and forest agroecosystems (2.9 years) and in the plantation agroecosystem (3 years). The age of the first female calf to have a baby in the four 
agroecosystems of Timor Island which is $>2.8$ years is influenced by the age of the first mating, at age 1.7 years. The heat cycle and heat period for female cattle in the pasture agroecosystem is 27 days and $21.5 \mathrm{~h}$, respectively in the forest agroecosystem 25 days and $26.8 \mathrm{~h}$ in agricultural agroecosystems 24 days and 28 hours and in the plantation agroecosystem 24 days and $25.8 \mathrm{~h}$. The results of this study indicate that the heat cycles for female cattle in the agroecosystems of agriculture and plantation are shorter than that of female cows in the forest and pasture agroecosystems. Meanwhile, the heat period of female Bali cattle in the four agroecosystems of the island of Timor shows a longer time, so, it is a good idea for breeders to schedule livestock mating for the effectiveness of the mating system for both natural mates and insemination mates. The average estrus cycle of cattle is 21 days or in the range of 18-24 days with estrus duration of 18-19 h. Dikman states that for the percentage of heat occurrence is $43 \%$ at $00.00-06.00 \mathrm{WIB}, 25 \%$ at 18.00 $00.00 \mathrm{WIB}, 22 \%$ at $06.00-12.00 \mathrm{WIB}$ and $10 \%$ at $12.00-$ 18.00 WIB.

The female cattle in the plantation agroecosystem needs 2.2 times to achieve service per conception compared to the cattle in the forest agroecosystem (2.3 times), pasture agroecosystem (2.4 times) and agricultural agroecosystem (2.6 times). Riwukore and Habaora ${ }^{[22]}$ stated that the S/C value is said to be normal between 1.62.0 and ideally female cattle that must experience pregnancy after performing IB 1-2 times during the mating process. This shows that female Bali cattle in the four agroecosystems of Timor island have a relatively low fertility value. Riwukore and Habaora ${ }^{[1]}$ states that the factors that influence the high $\mathrm{S} / \mathrm{C}$ value include the nutritional factor from the feed given. Lack of protein in female livestock rations can result in weak oestrus, repeated mating, premature embryonic death and embryonic abortion. The high value of $\mathrm{S} / \mathrm{C}$ is allegedly due to breeders being late in detecting oestrus or being late in reporting oestrus to inseminators, abnormalities in cow reproductive organs, lack of skilled inseminators, limited insemination service facilities and lack of smooth transportation (insufficient transportation) ${ }^{[24]}$. Inbreeding factor can be a problem because of an uncontrolled raising system. The results of this study indicate that the natural mating system is a system carried out by farmers in the four agroecosystems of the island of Timor with a percentage ranging from 86.67-92.91\%. Improved feed and reproduction management can reduce service per conception. Pramono et al. ${ }^{[21]}$ reported that improved feed and reproductive management could reduce S/C from 2.21.75.

Female cows in the plantation agroecosystem have a longer pregnancy period that is 9.5 months, compared to female cows in the agricultural agroecosystem (9.4 months) in the pasture agroecosystem (9.3 months) and in the forest agroecosystem (9.2 month). The length of pregnancy period in these four agroecosystems is still in the normal range of the length of local cattle pregnancy in Indonesia which is between 9.5-9.7 months. A pregnancy period is influenced by gender, cow breed, heredity, parent age, birth season, environmental conditions, raising management, feed, genetic and geographical location $^{[23,25,26]}$.

The results showed that the calf crop value of the cattle in the pasture agroecosystem (62.77\%) was higher than the cattle in the forest agroecosystem (54.74\%) in the agricultural agroecosystem (51.41\%) and in the plantation agroecosystem (32.74\%). The difference in calf crop value is influenced by the time and length of oestrus of female cattle in each agroecosystem. The calf crop value is influenced by the number of childbirth, the percentage of mother cows giving birth in the total parent population, the percentage of deaths when the child has not been weaned and spaced ${ }^{[24,25,27]}$. In an effort to increase calf crop of cattle, breeders must be precise in paying attention to the time and duration of oestrus, accuracy when mating, nutrition and disease control.

The female cows in the plantation agroecosystem show longer days open, i.e., 1.1 years, compared to the females in the forest agroecosystems (1 year) in the agricultural agroecosystem (9 months) and in the pasture agroecosystem (8 months). The results of this study indicate the DO value of Bali cattle in the four agroecosystems is very long. Ihsan states that the ideal DO is 85-115 days. Meanwhile, the length of DO cattle in Indonesia is between 116.09-149.32 days ${ }^{[27,28]}$. The long DO value for Bali cattle in the four agroecosystems of Timor island is caused by low reproductive management, limited feed and environmental factors. Novakovic etc., states that long DO values are affected by slow and incorrect oestrus detection, lack of body weight and environmental influences.

The female cattle in the forest agroecosystem have a higher conception rate (56\%) compared to the female cows in the agricultural agroecosystem (53.4\%), in the pasture agroecosystem (50.3\%) and in the plantation agroecosystem (33.7\%). The results of this study indicate that the value of the conception rate of Bali cattle in the plantation agroecosystem is very low. Good CR values of cattle are between $60-70 \%$ and the values of CR for beef cattle in Indonesia are considered good if the CR value of $45-50 \%{ }^{[23]}$. regarding natural conditions, management and wide distribution of livestock. CR values are low in the plantation agroecosystem because they have large S/C values and the fertility of males and females is low even though they already have inseminators in the very satisfying category. Afiati etc., states that the combination of livestock fertility levels (male, female fertility and insemination techniques) affects $80 \%$ of pregnancy values by $64-70 \%$. Livestock reproduction and selection 
management is a strategy in increasing the value of cattle $\mathrm{CR}$ in the four agroecosystems of the Timor Island, especially in the plantation agroecosystem.

Female cattle in in the plantation agroecosystem have longer calving interval value (2.8 years) than the females in the agricultural agroecosystem (2.7 years) in the pasture agroecosystem (2.5 years) and in the forest agroecosystem (2.4 years). The results of this study indicate that calving intervals for cattle in the four agroecosystems on Timor Island are very long. Setyono et al. ${ }^{27}$ states that the ideal calving interval for cattle is 365 days (12 months) where 9 months are for pregnancy and 3 months for breastfeeding. Calving interval for cattle in Indonesia is between $1.12-1.17$ years $^{[24,27]}$. The traditional mating and raising system is still the cause of the long CI value. Lutfi et al. ${ }^{[29]}$ stated that the CI value is significantly influenced by male groups and location, birth season related to feed availability. The calf is too long to feed by the mother with a limited feed nutrition will cause post partum etrus to be late and the calving intervals become long, making farmers suffer from a lose.

The percentage rate of livestock population increase per year is higher in Bali cattle in the forest agroecosystem (11.19\%) compared to Bali cattle in the pasture agroecosystem (11.06\%) in the agricultural agroecosystem (8.60\%) and in the plantation agroecosystem (7.44\%). The percentage increase in the population of female cattle in the four agroecosystems is influenced by the reproductive status of livestock. Thus the reproductive status of cattle in forest and pasture agroecosystems tends to be better than the reproductive status of cattle in the agroecosystems of agriculture and plantations.

Importance-performance analysis of Bali cattle productivity: The Importance Performance Analysis (IPA) method shows that the priority of improving the level of performance of each attribute/variable productivity of Bali cattle in each agroecosystem through a cartesian diagram is divided into four quadrants. Cartesian diagram is a diagram where on the $\mathrm{X}$ axis there is an average value of performance level and on the $\mathrm{Y}$ axis there is an average value of importance. As for the Cartesian Importance Performance Analysis (IPA) diagram for the productivity attributes of Bali cattle in the pasture, agriculture, plantation and forest agroecosystems are presented sequentially in Fig. 2-5. The notation picture description in the Cartesian diagram consists of 14 attributes/variables, namely body weight, body condition score, age of first heat, age of female first coitus, heat cycle, calf crop, heat duration, service per conception, length of calving, age of having first calf, days open calving interval, conception rate and rate of population increase.
The information in Fig. 2 about the results of the importance-performance analysis of Bali cattle productivity in the pasture agroecosystem shows that the performance attributes of Bali cattle productivity in the agroecosystem are only scattered in two quadrants, namely quadrant B and quadrant C. Quadrant B shows that the productivity performance attributes of Bali cattle in the pasture agroecosystem have shown good and satisfying results so that the performance of these animals needs to be maintained. The attributes that enter this quadrant are weight, calf crop and conception rate. Meanwhile, quadrant $\mathrm{C}$ shows that the attributes that are considered less important and in fact the performance is not too special. The attributes contained in this quadrant, namely SKT, oestrus age, first coitus age, oestrus cycle, oestrus duration, service per conception, long time of pregnancy, age of the first calf, days open, calving interval and rate of population increase. Thus the interested parties still have to improve the performance of the attributes in the $\mathrm{C}$ quadrant.

The information in Fig. 3 about the results of the importance-performance analysis of Bali cattle productivity in agricultural agroecosystems shows that the performance attributes of Bali cattle productivity in agricultural agroecosystems are only spread over two quadrants, namely quadrant B and quadrant C. Quadrant B shows that the performance attributes of Bali cattle productivity in agricultural agroecosystems have shown good and satisfying results so that the performance of these cattle needs to be maintained. The attributes that enter this quadrant are weight, calf crop and conception rate. In the meantime, quadrant $\mathrm{C}$ shows that the attributes that are considered less important and in fact the performance is not too special. The attributes contained in this quadrant, namely SKT, oestrus age, first coitus age, oestrus cycle, oestrus duration, service per conception, long time of pregnancy, age of the first calf, days open, calving interval and rate of population increase. Thus the interested parties still have to improve the performance of the attributes in the $\mathrm{C}$ quadrant.The information in Fig. 4 about the results of the importanceperformance analysis of Bali cattle productivity in plantation agroecosystems shows that the performance attributes of Bali cattle productivity in plantation agroecosystems are only spread over two quadrants, namely quadrant B and quadrant C. Quadrant B shows that the performance attributes of Bali cattle productivity in plantation agroecosystems have shown good and satisfying results, so that, the performance of these cattle needs to be maintained. The attributes that enter this quadrant are weight, calf crop and conception rate. Meanwhile, quadrant $\mathrm{C}$ shows that the attributes that are considered less important and in fact the performance is not too special. The attributes contained in this quadrant, namely SKT, oestrus age, first coitus age, oestrus cycle, oestrus duration, service per conception, long time of 


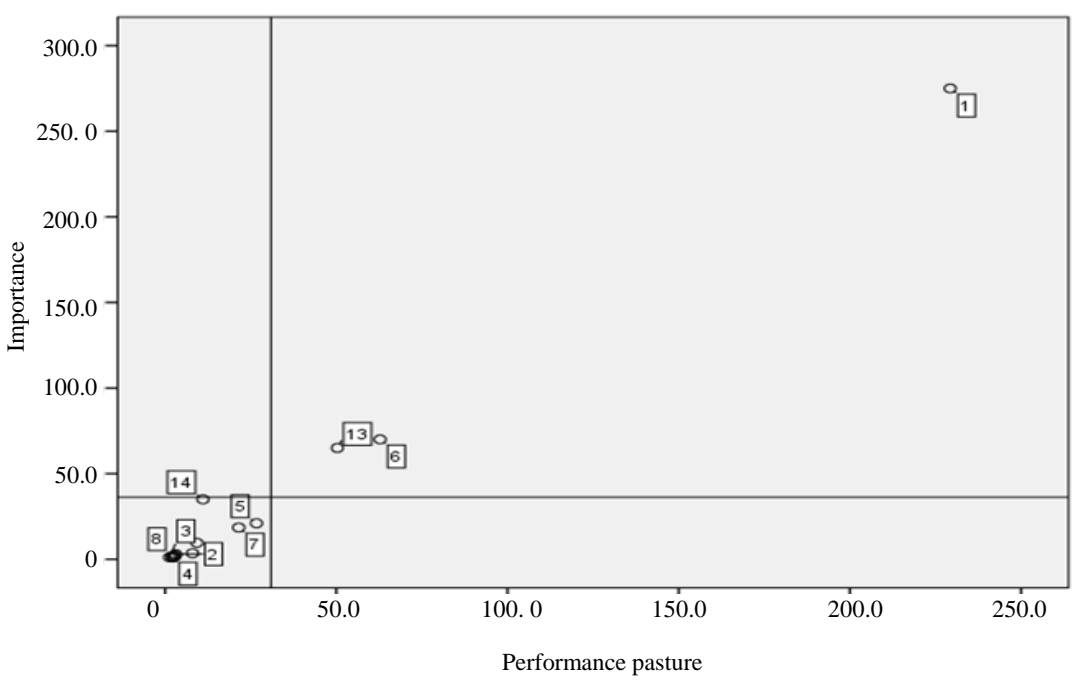

Fig. 2: Importance-performance analysis of Bali cattle productivity in the pasture agroecosystem

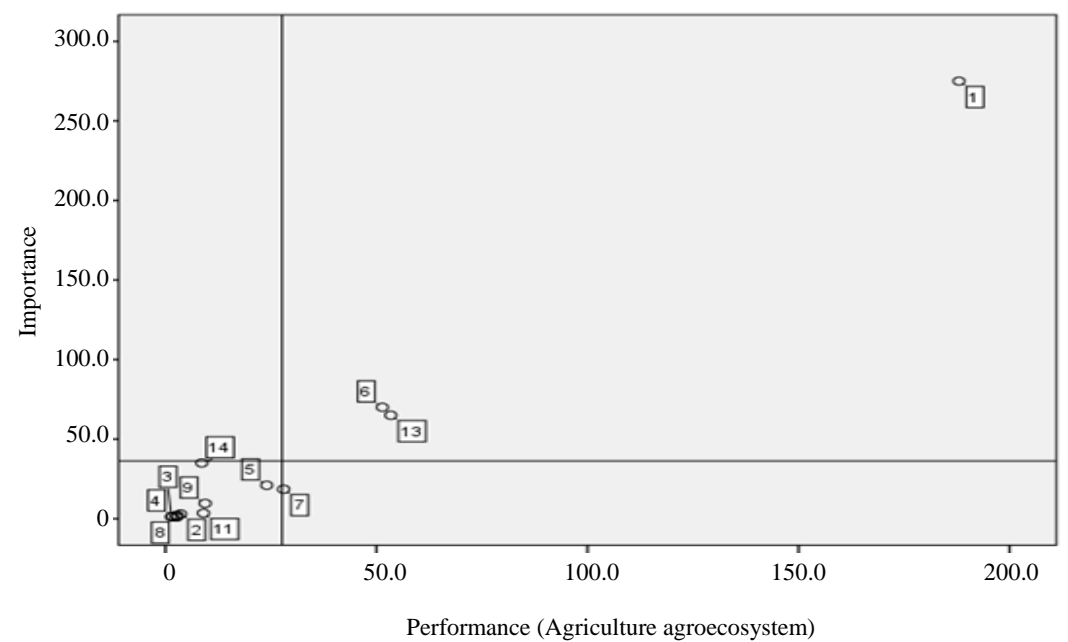

Fig. 3: Importance-performance analysis of Bali cattle productivity in the agriculture agroecosystem

pregnancy, age of the first calf, days open, calving intervaland rate of population increase. Thus the parties concerned (breeders and the government) still have to improve the performance of the attributes that are in quadrant C.

The information in Fig. 5 about the results of the importance-performance analysis of Bali cattle productivity in the forest agroecosystem shows that the performance attributes of Bali cattle productivity in the forest agroecosystem are only scattered in two quadrants, namely quadrant B and quadrant C. Quadrant B shows that the performance attributes of Bali cattle productivity in forest agroecosystems have shown good and satisfying results, so that, the performance of these cattle needs to be maintained. The attributes that enter this quadrant are weight, calf crop and conception rate. Meanwhile, quadrant $\mathrm{C}$ shows that the attributes that are considered less important and in fact the performance is not too special. The attributes contained in this quadrant, namely SKT, oestrus age, first coitus age, oestrus cycle, oestrus duration, service per conception, long time of pregnancy, age of the first calf, days open, calving interval and rate of population increase. Thus the parties concerned (breeders and the government) still have to improve the performance of the attributes that are in quadrant $\mathrm{C}$.

In general, the level of importance and performance of Bali cattle in pasture, agriculture, plantation and forest agroecosystems shows the same conditions where the performance (productivity) of Bali cattle in each agroecosystem has been good for the attributes of body weight, calf crop and conception rate. Meanwhile, the attributes that need to be considered and improved the 


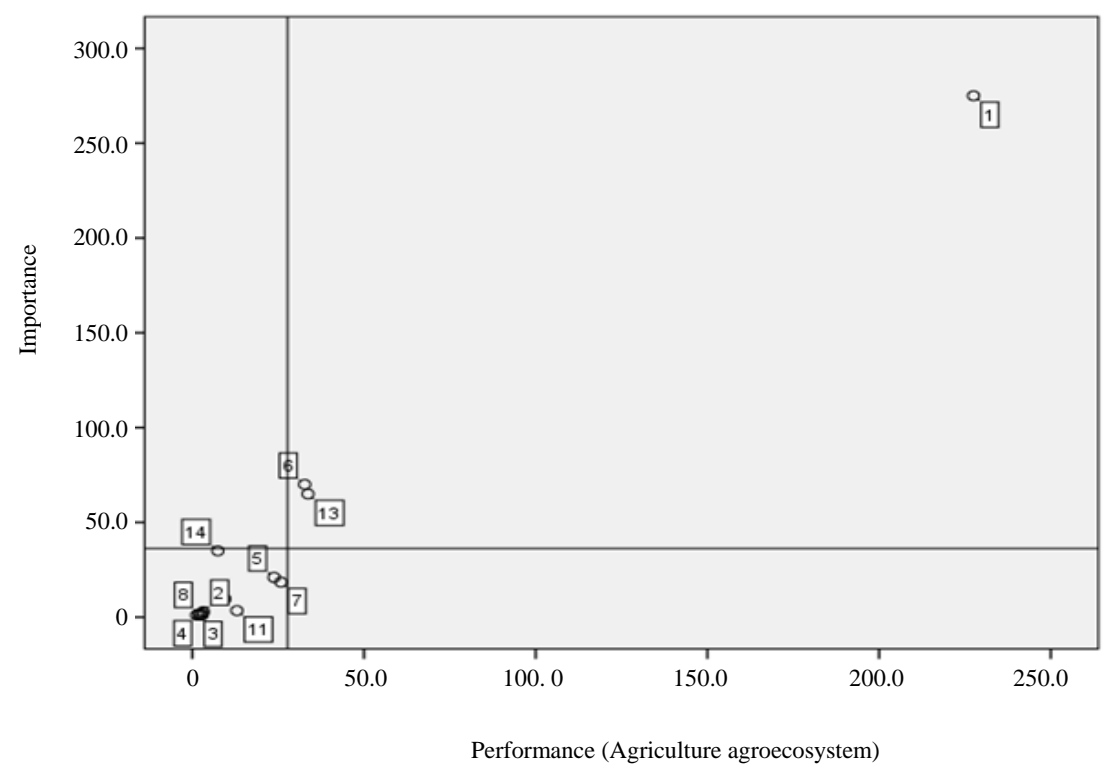

Fig. 4: Importance-performance analysis of Bali cattle productivity in the plantations agroecosystem

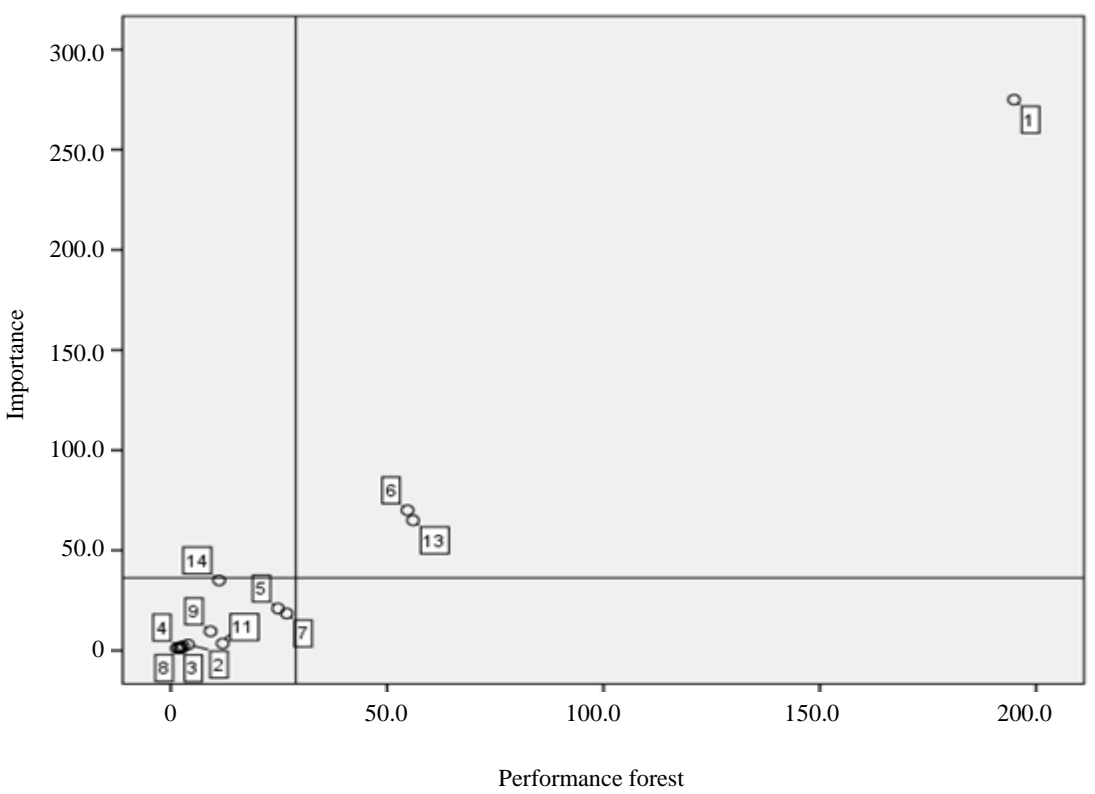

Fig. 5: Importance-performance analysis of Bali cattle productivity in the forest agroecosystem

quality and quantity are SKT, oestrus age, first coitus age, oestrus cycle, oestrus duration, service per conception, long time of pregnancy, age of the first calf, days open, calving interval and rate of population increase. The circumstances of this study indicate that the productivity of Bali cattle distributed in pasture, agriculture, plantation and forest agro-ecosystems in general is low. This is in accordance with the results of several studies that report that the increase in population and productivity of Bali cattle on Timor Island and in NTT is generally still relatively low due to several reasons including: high calf mortality (35-40\% per year); high parent mortality ( $>20 \%$ per year); productive female cattle slaughter in $\mathrm{RPH}$ reaches $>60 \%$ of total cattle slaughter; feed limitations due to seasonality; traditional livestock raising systems with low production inputs; the occurrence of endemic brucellosis and antrax with a high prevalence $(14.57-40.76 \%)$ in the last 10 years; supervision of livestock exports is still weak, so that, the realization of exports is higher than the stipulated quota; there was a 
decrease in the weight of Bali cattle exports from $450 \mathrm{~kg} \mathrm{head}^{-1}$ in 1970-1980-275 kg head ${ }^{-1}$ in 2015 $5^{[4,5,8 \text {, }}$ $9,10,11,12,30]$. Based on this condition, it is necessary to improve the performance of agroecosystem based Bali cattle in accordance with the potential of resources and the environment. For this reason, it is recommended that the development of Bali cattle farms on Timor island be a regional/agroecosystem model.

\section{CONCLUSION}

Based on the analysis and sequence of interests, the productivity of Bali cattle in the pasture, agriculture, plantation and forest agroecosystems on the island of Timor shows relatively similar results and still meets fairly good standards for the production aspects of weight attributes, calf crop and conception rate. Attributes that need to be improved in terms of quality and quantity are reproductive capacity which includes, oestrus age, first coitus age, oestrus cycle, oestrus duration, service per conception, length of calf pregnancy, age of first calving, days open, calving interval and rate of increase population. Overall, it can be concluded that the productivity of Bali cattle distributed in pasture, agriculture, plantation and forest agro-ecosystems needs to be improved and supported by strong local government policies and contributions from stakeholders towards improving land and feed quality to support efforts to improve production quality and reproduction of Bali cattle in each agoecosystem.

\section{REFERENCES}

01. Riwukore, J.R. and F. Habaora, 2019. Beef cattle productivity development strategy at pasture Konetuef. Int. J. Curr. Res. (IJCR.), 11: 4244-4247.

02. Habaora, F., A.M. Fuah, L. Abdullah, R. Priyanto, A. Yani and B.P. Purwanto, 2019. Economic analysis of Bali cattle farm in Timor Island Indonesia. Int. J. Sci. Technol. Res., 8: 1576-1582.

03. Habaora, F., A.M. Fuah, L. Abdullah, R. Priyanto, A. Yani and B.P. Purwanto, 2019. Attitude analysis of Bali cattle farmers toward credit programs based on Agroecosystems in Timor Island. Int. J. Innovative Sci. Res. Technol., 4: 769-776.

04. Riwukore, J.R. and F. Habaora, 2019. Perception of farmers on the performance of extensionist in the pasture agroecosystem of Timor Tengah Utara district. Asian J. Agric. Extension, Econom. Sociol., 29: 1-10.

05. Kleden, M.M., M.R.D. Ratu and M.D.S. Randu, 2015. Carrying capacity of forage in coffee farm and native pasture area at District of Flores Timur-East Nusa Tenggara. J. Zootrek, 35: 340-350.
06. Lole, U.R., S. Hartoyo and I.W. Rusastra, 2013. Analysis of regional distribution capacity and priorities for improving beef cattle population in East Nusa Tenggara Province. Media Peternakan, 36: 70-78.

07. Mahbubi, A., 2015. Development program of Madura as an Island of Cattle: Sustainable supply chain management perspective. J. Agriekonomika, 3: 94-105.

08. Mullik, M. and I.G.N. Jelantik, 2009. Strategies for increasing Bali cattle productivity in extensive maintenance systems in Dryland areas: The experience of East Nusa Tenggara. Proceedings of the National Seminar on Sustainable Development of Bali Cattle in the People's Livestock System, October 28, 2009, Mataram, pp: 1-15.

09. Priyanto, D., 2016. Strategies to return East Nusa Tenggara as a source of beef cattle. J. Litbang Pertanian., 35: 167-178.

10. Saptana, and N. Ilham, 2017. Supply chain management of cattle and beef commodities. J. Agric. Policy Anal., 15: 83-98.

11. Tahuk, P.K. and A.A. Dethan, 2010. Performance of Bali bull in greenlot fattening by farmers when rainy season in Timor Island. J. Indonesian Trop. Anim. Agric., 35: 257-261.

12. Wirdahayati, R.B., 2010. Application of technology on improving beef cattle productivity in East Nusa Tenggara. WARTAZOA. Indonesian Bul. Anim. Vet. Sci., 20: 12-20.

13. Surahmah, N. and E. The, 2011. The estimation of body weight of bulls candidate of Bali cattle using some body dimension. Buletin Pet., 35: 160-164.

14. Algifari, 2019. Measuring Service Quality with Satisfaction Index, Importance-Performance Analysis (IPA) Method and Canoe Model. 2rd Edn., BPFE-Yogyakarta Press, Yogyakarta, Indonesia,.

15. Warwick, E.J., J.M. Astuti and W. Hardjosubroto, 1995. Animal Breeding. Gadjah Mada University Press, Yogyakarta.

16. Ismail, M., N. Nuraini and R. Priyanto, 2014. Effect of body fatness to carcass and non carcass productivity of small frame size beef cattle (Bali and Madura cattle). J. Vet., 15: 411-424.

17. Gunawan, A., R. Priyanto, C. Sumantri and J. Arifin, 2017. Uniformity and adjacency morphometrics body size of pasundan cattle. J. Vet., 18: 263-273.

18. Baharun, A., H.L. Belli and T.M. Hine, 2017. Characteristic of Bali cattle young bull under traditionally livestock system in Merbaun Village Regency of Kupang. J. Pet. Nusantara., 3: 11-16.

19. Herold, P., A. Markemann and A.V. Zarate, 2011. Resource use, cattle performance and output patterns on different farm types in a mountainous province of Northern Vietnam. Anim. Prod. Sci., 51: 650-661. 
20. Sodiq, S. and P. Yuwono, 2016. Development type and productivity of beef cattle at the community development partnership program in Banyumas and Cilacap Regencies of Central Java Province. J. Agripet., 16: 56-61.

21. Sodiq, S. and P. Yuwono, 2016. Development type and productivity of beef cattle at the community development partnership program in Banyumas and Cilacap Regencies of Central Java Province. J. Agripet., 16: 56-61.

22. Suretno, N.D., B.P. Purwanto, R. Priyanto and I. Supriyatna, 2017. Environmental suitability evaluation based on the performance production four breed cattles on some different altitudes in Lampung Province. J. Vet., 18: 478-486.

23. Habaora, F., A.M. Fuah, L. Abdullah, R. Priyanto, A. Yani and B.P. Purwanto, 2019. Reproduction performance of Bali cattle on agroecosystem in Timor Island. Ternak Tropika J. Trop. Anim. Prod., 20: 141-156.

24. Soeharsono, R.A., Saptati and K. Diwyanto, 2010. Local fattening cattle resulting from artificial insemination and imported feeder cattle using local feed ingredients. Proceedings of the National Seminar on Animal Husbandry and Veterinary Technology, August 3-4, 2010, Bogor, Indonesia, pp: 115-122.
25. Iskandar, 2011. Reproductive performance of PO cattle in the lowlands and highlands in Jambi Province. Sci. J. Anim. Sci., 14: 51-61.

26. Prasojo, G., I. Arifiantini and K. Mohamad, 2010. Correlation between length of pregnancy, birth weight and sex of calf resulted from artificial insemination in Bali cattle. J. Vet., 11: 41-45.

27. Setiyono, S., A.H.A. Kusuma and R. Rusman, 2017. Effect of breed, age and sex on quality of beef in special region of Yogyakarta. BuletinPeternak, 41: 176-186.

28. Atabany, A., B.P. Purwanto, T. Toharmat and A. Anggraeni, 2011. The impact of days open on milk performance of Friesian Holstein cows in Baturraden, Indonesia. Med. Peternakan, 34: 77-82.

29. Luthfi, M., Y.N. Anggraeny and Purwanto, 2011. Differences in reproductive performance of $\mathrm{PO}$ and brahman cross cattle in various locations in Central and East Java. Beef Cattle Research Station, Grati, Pasuruan, Indonesia.

30. Nuryadi and S. Wahjuningsih, 2011. Reproduction performance of Ongole and Peranakan Limousin cattle in Malang Regency. J. Trop. Livestock, 12: 76-81. 